priests of the hospital. The date of the foundation of the hospital is believed to be 1084. The clerks of St. Gregory are named in the Christ Church Domesday" ("little if at all later then the Conqueror's-reign'"), and in terms which make it more than likely that the clerks of Canterbury, who held thirty-two mansivac in gildam suam, according to Domesday Book, are none other than the clerks of St. Gregory.

MIARY Bateson.

Cotton Irs. Faust, C.I. f. 17 a.

De Scola de cantib.

Universis sancte dei ecclesie filiis Henricus archidiaconus Huntingdon ${ }^{r}$ salutem in Christo. Quia negaciis et commoditati maxime eorum qui renunciaverant seculo et militant Christo omnimoda eorum indempnitate sollicite providere, et ne dampnosa temporum interieccio antiquet et obnubulet ${ }^{7}$ si quid misit in dubium quod eorum ad veri fidem trahi possit assercione, in lucem evocare pia et honests curscio est, vestram dignum duximus non latere noticiam nos canonicis de Huntingdon' scolss de cantu de Huntingdon' quas ad ius eorum dinoscitur pertinere in perpetoum reddidisse et super altare obtulisse. Valete.

\title{
Adluc do Scolis.
}

$\mathrm{R}$ [obertus] dei gracis Lincolniensis episcopus $\mathrm{H}$ [enrico] Archidiacono et decanis suis de Huntingdonschira salutem. Conquesti sunt nobis canonici de Huntingdon' quod quidar contra tenorem domini pape privilegii et. nostram confirmacionem in preiudicium scolarum de Huntingdon' presumunt adulterinas scolas regere absque eorum licencia, eapropter vobis mandando precipimus at omni negligencia [remota] ${ }^{R}$ sollicicius eis de cetero silencium inponatis nostra suctoritate, quod si contempserint non. differatis ecclesiam illins loci in cuius parochia scolas illicite regi ad ${ }^{9}$ suspendere, et non relaxentur donec satigfecerint nobis et canonicis. Valete.

\section{Early Posts in England.}

THe history of the English post office bns been written by William Lewins and Herbert Joyce, who were both officers of the department, and told the story of the growth of the postal service with considerable fulness of detail; but neither writer devoted much attention to the origin of the post office, and some of their statements need correction in view of the publication of Calcndars of the State Papers, which were either not available or were not consulted by them. The common books of reference are also misleading as to the origin of the English posts, which are traced no

4omner, ed. Battely, i., app., p. 4 J.

- D.B. 1. $3 \mathrm{a}$.

- Round, Feudal England, p. 300.

- A blank space has been left for the missing word. ' Sic for abnubilet. the present writer to St. Martin's.le.Cirand, xiii. 131-0, April 1903. 
further back than c. 1533 : ander this date some have noted the existence of a master of the posts, while others have not recognised him until 1581. But the king's posts certainly existed as early as 1509,2 and a letter at the Record Office from Francis de Taxis, master of the posts in Flanders, addressed Magistro Domino meo Brianno Tuke, Magistro Postarun, Londini, bears the date of 23 March 1516. We know, moreover, that Tuke was master of the posts in 1512, as there are numerous entries of payments made to him and to others for posts from October in that year and onwards until Tuke's desih in 1545 .

It must not be supposed that the postal service at the beginming of the sixteenth century, or indeed at any period of that centary, was carried on for the benefit of the public at large, or that the conveyance of letters and packets was the chief object of the posts. In the eighteenth century, we are told,

les postes sont des relais des ohevaux établis de distance en distance a l'usage des courriers chargés de porter les misaives tant du souperain que des particuliers ; ces relais servent angei à tous les vojageurs qui veulent en user en payant toutefoie le prix réglé par le gouvernement."

But this definition, accurate though it may be as regards the

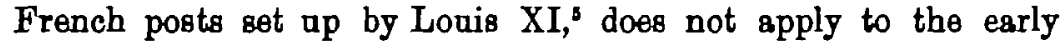
English posts in so far as private letters and private travellers are concerned. The English posts were the king's posts for the conveyance of persons travelling on his business, or of letters and packets sent on his eervice. If an ordinary traveller wished to ride post, he must first obtain a commission, or warrant, from the sovereign, his privy conncil, or certain officers of state; and though private letters circulated by the post in the reign of Elizabeth, and probably earlier, they were treated as 'bye' letters, and had to take their chance of being forwarded as opportunity occurred.

The patent of Brian Tuke's appointment is not forthcoming. His successors were William Paget, secretary of state, who does not, however, seem to heve acted, and John Mason, French tary, to whom letters patent were issued on 12 Nov. 1545, granting to them, or the survivor of them, Officium Magistri Nunciorum Cursorum sive Postarum tam infra regtium nostrum Angliae quam in aliis partibus transmaninis in nostro dominio existentibus, with 8 pension of $66 l$. 198. 4d. \& year, to hold, occupy, or enjoy by themselves or their sufficient deputies, during their own lives, or the

- Letters and Papers, Hen. VLI, vol. i. no. 8916.

- Francis do Taxis to Brian Tuke, Letters ard Papers, Hem. VIII, vol. ii. no. 1698.

' Diderot, Encycloptdic, 8.v. ' Poste.'

- Commynes, Mtmoires, v. 10, mentions them ander the year 1477; they had been established by a royal ordinance in 1464. Soe B. do Mandrot's note ad loc (rol. i. p. 268, 1901). 
life of the longer liver of them, with all profits and commodities of the office in as full and large a manner as Brian Tuke, or any other persons, held the said office. Mason continued to hold the office until his death in 1566, but he was often out of the country on other state business, and at one time apparently for three years. His successor, Thomas Randolph, was appointed master of the posts in 1566, and died 8 June 1590 , but he too wes often out of England, going as ambassedor to Russia in 1568 and to France in 1573 and 1576 . On 20 June 1590 a new patent was made out granting the office of master of the posts to John, first Baron Stanhope of Harrington, whose son was by a subsequent patent associated with him in the office with the right of succession. This second patent was the subject of protracted litigation and of appesls to parliament. A pamphlet setting forth the Stanhope case is preserved at the Record Office. ${ }^{6}$

It is clear from the state papers that there were posts to Berwick and Calais from 1509 onwards. A payment was made in that year to Lord Darcy, warden of the east and middle marches against Scotland, for posts to Berwick, and this northern post seems to have been maintained from that date without serious interruption. There were also regular posts to Calais, or to Dover after the loss of Calais, for, writing in 1535 to Lord Lisle, governor of Calais, Tuke said, "There are always ordinary posts from London to Dover.' 7 The regular post to Ireland was of later date; but in 1575 there were three regular lines of poste from London-namely, to Berwick, Holyhead, and Dover. A list of the stages is printed below. ${ }^{8}$ There were also posts, as occasion required, to other places-e.g. to Exeter, to York-presumably from some stage on the Berwick road-and to Portsmouth; but these posts were withdrawn as soon as the necessity for them ceased. Posts were also laid to the court, wherever the sovereign happened to be. Thus in Take's letter of 1585, already referred to, he says, 'Wherever the king is posts are laid to his grace;' and when Queen Elizabeth went on a progress in the summer of 1578 a warrant was issued by the council to Gascoyne, the postmaster of the court, directing him to provide for the conveyance of letters to and from the court during her majesty's progress. ${ }^{\circ}$

In addition to the king's post there was a post to the outports set up by the ulien merchants in London in 1514. The English merchants who ased this post for the conveyance of their letters to and from the continent frequently complained that their corre-

- Bee Calendar of State Papers, Domestic, Charles I, 1645-7, p. 161.

- Lotters and Paper, Hen. VIII, vol. ix. no. 27.

- It is taken from a paper entitled 'England, Matters of Stata and Force of the Kingdom,' State Papers, Domestic, Eliz., vol. rcvi. 1574.

- Acto of the Privy Council, 14 Jaly 1578. 
spondence was kept back to their disadvantage, and sometimes the alien merchants quarrelled among themselves as to the control of their post, which was at last absorbed into the king's post. ${ }^{10}$

Regulations for the control of the posts were made by the privy council at Westminster, 14 Jan. 1588. Sundry inconveniences had arisen from 'the over great liberty of late used in riding post,' and dirers of her majesty's good subjects had complained that they had been oppressed. A proclamation was therefore issued, bearing the signatures of ten councillors, for the purpose of controlling the posts, and directing that persons having the place of an ordinary post must reside and not discharge their daties by deputy. Persons riding in post by commission must take their horses of the post and pay $1 \frac{1}{2} d$. a mile for each horse; those who rode urgently without commission were to pay $2 d$. a mile (the council had more then once forbidden riding post without a commission, but this requirement had been often evaded and was now withdrawn). The names of persons riding post were to be recorded in a book. If there were not enough post horses, other horses were to be taken, with the assistance of mayors and constables, and the owners paid at the ordinary rates. Riders were to be accompanied by a guide, who was to blow his horn when meeting company, in passing through towns, and at least thrice every mile. No packet or letter was to be forwarded specially except on her majesty's affairs. The posts were to ride in summer seven miles an hour, and in winter five miles an hour, so as to make the journey from London to Berwick in forty-two or sixty hours, according to the season. Finally, hackney men carrying packets or serving horses were to he punished.

A few days after the issue of this proclamation Randolph, as 'master and controller-general of all her majesty's posts,' set down erticles for the posts between London and the northern border against Scotland. These articles were supplementary to the regulations made by the council, and provided that each post was to heve three good and sufficient horses, three good and strong leather bags, and three horns, and four horses, either his own or others, and two horns for those riding post. The guide who accompanied persons riding post was to carry luggage to the weight of forty pounds. Packets on her majesty's service were to be sent forward within a quarter of an hour of their receipt, were not to be carried except by servants of the post, and were to be delivered before private letters. On 29 Jan. 1584 orders were set down by Lord Cobham, warden of the Cinque Ports, and by Randolph for the posts to Dover. They do not differ materially from the articles of the previous year for regulating the northern posts, but they contain directions as to strangers going in and out of the realm, and as to the ordinary through posts for the service of merchants for Flanders and France.

1- Report of the Secret Commitied on the Post Office, 1844, appendix. 
The early posts were, as we have seen, intended solely for the service of the sovereign, and it is clear from the regulations made by the privy council and from Randolph's articles of 1583 that private letters were only carried on sufferance. It is difficult to ascertain when this practice began, and some statements on the subject that have appeared in print do not seem well founded. In Lewins's Hor Majcsty's Mails it is said that 'several letters are in existence dating as far back as the reign of Edward II which have the appearance of having been carried by the nuncii of the period, with "Haste, post haste " written on the back of them.' I think this statement must have been made under a misapprehension, for the word 'post' in this sense does not seem to have come into our language until the end of the fifteenth or the beginning of the sixteenth century. According to the first report of the postmastergeneral (1855) private letters endorsed 'Post haste' and dated at the end of the fifteenth or the beginning of the sixteenth century were known to exist, bat I have made unsuccessful attempts to discover where such letters are to be found, and I am sceptical about them. The practice of marking official and other letters with such phrases as 'For life,' or 'Post haste,' beceme common enough in the middle of the sixteenth century. Thus in $\mathbf{1 5 4 8}$ Thomas, Lord Wharton, complained to the Protector that a packet marked to the post 'For life, for life' was nine days in reaching Carlisle; and in the same year Lord Grey, writing from Berwick to John Uvedale, treasurer for the garrisons in the north, marked his letter 'Haste' six times, 'For life' three times, and added a rade sketch of a gallowe, much to poor Uvedale's annoyance. But these were official, not private letters, and I am induced to think that in the sixteenth century private letters, when not despatched by special messengers, were usually entrusted to the carriers. Some of the Paston letters were so sent, ${ }^{11}$ and the practice was continued long after regular posts had heen established on the chief roads of the country. When, in the reign of Charles II, Henry Bisshopp, who farmed the post office, set up and advertised new posts, he claimed for them that they were more speedy and as cheap as the carriers. It was not, indeed, until the passing of the act 9 Anne, c. 11, that carriers were forlhidden by law to convey private letters.

J. A. J. HOUSDEN.

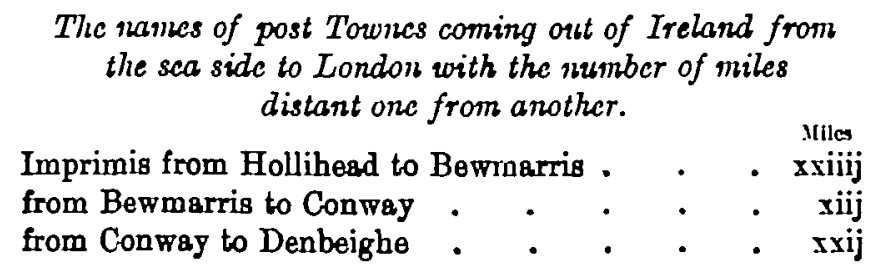

"John Paston to Mary Paston, 7 Ang. 1465. 


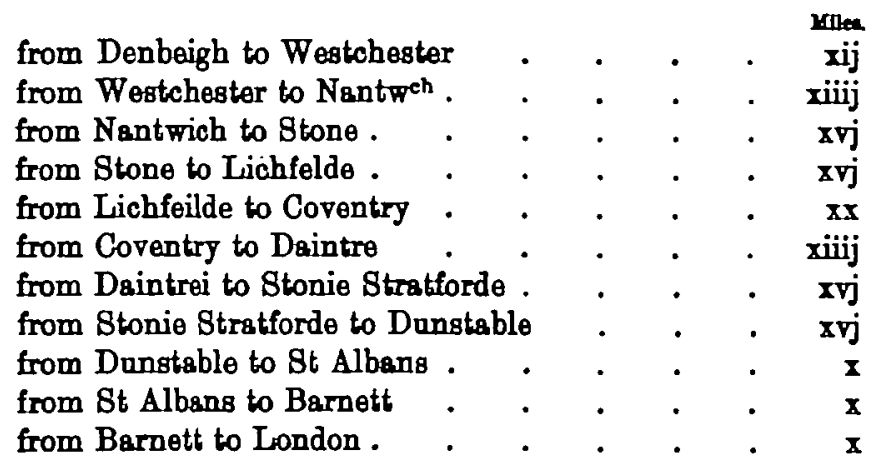

Posts from London to Dover.

from London to Dertect from Dartford to Rochester . . . . . . . xij from Rochester to Sittingborne $\quad . \quad$. . . . v vij from Sittingborne to Canterburie . . . . r rij from Canterburie to Dover . . . . . $\quad \mathrm{xij}^{12}$

The names of all the Townes where the postes ars betweene Barwicke at the Courte.

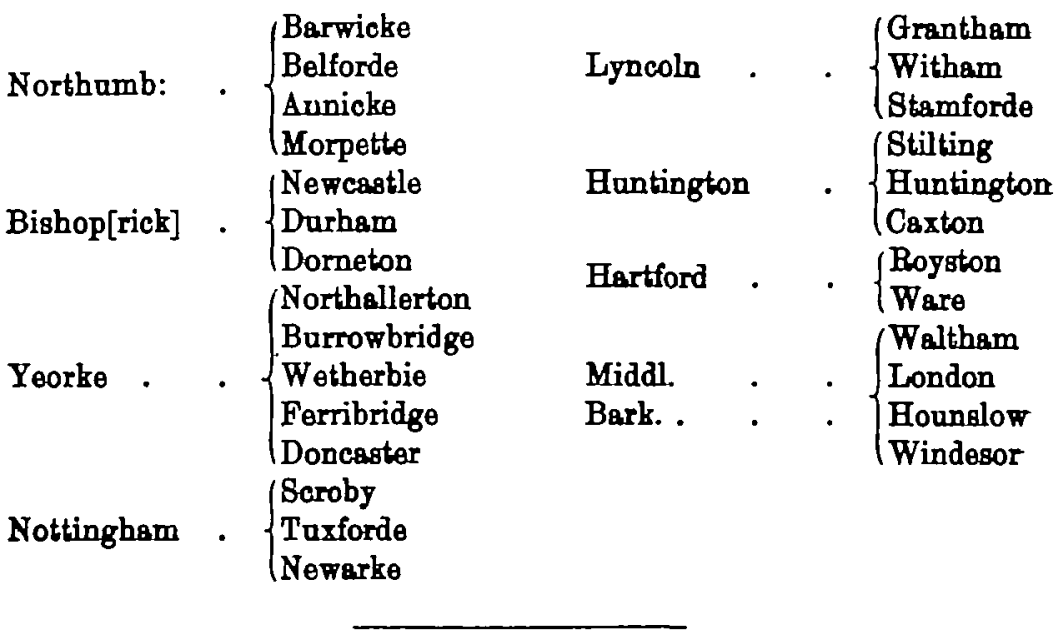

\section{The Neapolutan Stuarts.}

Mr. A. F. Stredart's paper in the last number of the English Historical Retiezo is, I venture to think, worth supplementing with some additional information, which I have lately acquired, relating

12 In almost every instance the distance between the post towns is understated. It appears from Javce's Eistory of the Past Office (chep. x. pp. 175-7) that attention was often called to the errors, bat they pere not corrected antil the middle of the eighteenth century. Joyos also points ont that in some old road-books the distance betreen tro places is stated differenfly in columns markod c (compated distarice) and 4 (mesarared distance) pespectively. 